\title{
HUBUNGAN KEPEMIMPINAN KEPALA MADRASAH DAN PRESTASI KERJA GURU DENGAN KEMAJUAN MADRASAH ALIYAH SE-KABUPATEN SURAKARTA
}

\author{
Angga Eka Yuda Wibawa \\ IAIN Surakarta \\ Email: anggaeyw17@gmail.com
}

\begin{abstract}
ABSTRAK
Penelitian ini bertujuan untuk mengetahui: (1) hubungan antara kepemimpinan Kepala Madrasah dengan kemajuan Madrasah Aliyah se-Kabupaten Surakarta, (2) hubungan antara prestasi kerja guru dengan kemajuan Madrasah Aliyah se-Kabupaten Surakarta, dan (3). hubungan antara kepemimpinan Kepala Madrasah dan prestasi kerja guru secara bersama dengan kemajuan Madrasah Aliyah se-Kabupaten Surakarta. Penelitian ini menggunakan pendekatan studi korelasional. Data yang digunakan adalah data primer dengan cara menyebarkan kuesioner kepada 30 orang sampel penelitian yang terdiri dari kepala madrasah dan guru Madrasah Aliyah se-Kabupaten Surakarta. Hasil pengumpulan data selanjutnya dianalisis menggunakan teknik analisis korelasi dan analisis regresi dengan bantuan Program IBM SPSS (Statistical Product and Service Solution) Statitics versi 21. Hasil penelitian ini menunjukkan bahwa: (1) ada hubungan yang signifikan antara kepemimpinan kepala madrasah dengan kemajuan madrasah sebesar 95,3\%, sedangkan korelasi partial antara kepemimpinan kepala madrasah dengan kemajuan madrasah sebesar 64\%, dan kepemimpinan kepala madrasah akan memberikan kontribusi terhadap kemajuan Madrasah Aliyah se-Kabupaten Surakarta sebesar 90,7\%; (2) Ada hubungan yang signifikan antara prestasi kerja guru dengan kemajuan madrasah sebesar $98,8 \%$, sedangkan korelasi partial antara prestasi kerja guru dengan kemajuan madrasah sebesar 86,1\%, dan prestasi kerja guru akan memberikan kontribusi terhadap kemajuan Madrasah Aliyah se-Kabupaten Surakarta sebesar 97,7\%; serta (3) Ada hubungan yang signifikan secara bersama antara kepemimpinan kepala madrasah dan prestasi kerja guru dengan kemajuan madrasah sebesar 98,8\%, kepemimpinan kepala madrasah dan prestasi kerja guru akan memberikan kontribusi secara bersama terhadap kemajuan Madrasah Aliyah seKabupaten Surakarta sebesar 97,7\%, sedangkan persamaan garis regresinya adalah: Y $=59,301+0,154 \mathrm{X} 1+$ $0,571 \mathrm{X} 2$.
\end{abstract}

\section{Kata kunci: Kepemimpinan, Prestasi Kerja Guru, Kemajuan Madrasah}

\section{Pendahuluan}

Pengelolaan satuan pendidikan juga menjadi salah satu perhatian pemerintah yang tertuang dalam Peraturan Pemerintah Nomor 19 Tahun 2005. Pasal 49 berbunyi: pengelolaan satuan pendidikan pada jenjang pendidikan dasar dan menengah menerapkan manajemen berbasis sekolah yang ditunjukkan dengan kemandirian,

kemitraan, partisipasi, keterbukaan, dan akuntabilitas. Pasal 50 berbunyi: setiap satuan pendidikan dipimpin oleh seorang kepala sekolah/madrasah sebagai penanggung jawab pengelolaan pendidikan.

Seorang kepala madrasah mempunyai tugas untuk mengatur dan menggerakkan sejumlah besar orang-orang (guru) yang mempunyai berbagai sikap, tingkah laku dan latar belakang yang berbeda-beda. Untuk mendapatkan guru yang dapat membantu tugas pimpinan secara optimal dan meningkatkan ke- majuan madrasah, maka diperlukan seorang pemimpin yang mampu mengarahkan dan merubah tingkah laku bawahannya kepada tercapainya tujuan organisasi secara maksimal.

Keberhasilan dan kemajuan madrasah salah satunya juga dapat dilihat dari prestasi kerja guru. Prestasi kerja guru dapat dilihat dari kualitas kerja, kuantitas kerja, kreativitas kerja, disiplin dan kerjasama guru.

Dengan memiliki motivasi dan tanggungjawab serta loyalitas guru terhadap pekerjaan maka akan menghasilkan guru yang professional sesuai kompetensi yang harus dimiliki sehingga akan berdampak pada prestasi siswa dan prestasi madrasah yang unggul dan mampu bersaing dengan madrasah lain serta menghasilkan siswa yang bermutu dan berprestasi. Semakin banyak prestasi siswa yang ditoreh maka semakin baik dan maju madrasah 


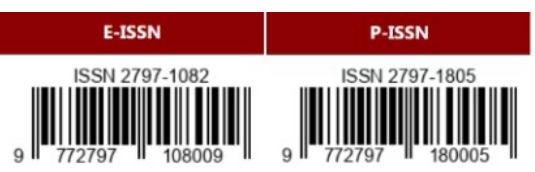

itu. Hal ini tentunya tidak lepas dari bimbingan dalam proses belajar mengajar oleh guru serta sarana prasarana yang mendukung serta tidak kalah pentingnya adalah peranan dari kepemimpinanan kepala madrasah dan prestasi kerja guru.

Guru adalah pendidik profesional dengan tugas utama mendidik, mengajar, membimbing, mengarahkan, melatih, menilai, dan mengevaluasi peserta didik. Namun ada sebagian guru hanya sekedar melepaskan kewajiban sebagai pengajar saja, disiplin yang kurang, tidak memiliki rencana pembelajaran yang baik, kurang kreatif dan kualitas kerja yang masih rendah. Hal ini dapat dilihat dari hanya sebagian kecil guru Madrasah Aliyah se-Kabupaten Surakarta yang berprestasi sampai ke tingkat Nasional baik dalam bidang kreativitas maupun prestasi akademik yang membanggakan daerah. Untuk bisa berprestasi setiap guru harus memiliki sejumlah kompetensi mengajar yang dipersyaratkan sehingga bisa mengenali, mengelola dan memotivasi diri dan orang lain untuk saling bekerja sama dalam meningkatkan prestasi diri dan tentunya kondisi madrasah yang kondusif dan kepemimpinan kepala madrasah sangat menentukan keberhasilan kinerja guru untuk berprestasi yang tentunya akan berdampak pada peningkatan mutu pendidikan.

Hubungan kepemimpinan kepala madrasah dengan kemajuan Madrasah Aliyah sangat erat sebab tugas penting seorang pemimpin adalah mendefinisikan misi dan peranan organisasi, pengejawantahan tujuan organisasi, mempertahankan keutuhan organisasi dan mengendalikan konflik internal yang terjadi di dalam organisasi.

Prestasi guru juga mempunyai hubungan yang sangat erat dengan kemajuan suatu lembaga pendidikan, sebab prestasi kerja guru dalam penelitian ini diartikan sebagai kemampuan kerja guru dalam melaksanakan tugas yang menjadi tanggung jawabnya guna mencapai hasil yang terbaik, bekerja sama dengan teman sejawat dalam menyelesaikan berbagai masalah pekerjaan.

Kemajuan madrasah adalah adanya perubahan baik secara kualitas maupun kuantitas mengenai madrasah tersebut. Kemajuan madrasah disesuaiakan dengan standar nasional pendidikan yaitu standar isi, proses, kompetensi lulusan, tenaga kependidikan, sarana dan prasarana, pengelolaan, pembiayaan dan penilaian pendidikan.

Berdasarkan latar belakang di atas maka perlu dilakukan penelitian menyeluruh dengan judul "Hubungan Kepemimpinan Kepala Madrasah dan Prestasi Kerja Guru dengan Kemajuan Madrasah Aliyah Se-Kabupaten Surakarta."

Adapun tujuan penelitian ini adalah untuk:

(1) mengetahui hubungan signifikan antara kepemimpinan kepala madrasah dengan kemajuan Madrasah Aliyah se-Kabupaten Surakarta, (2) mengetahui hubungan signifikan antara prestasi kerja guru dengan kemajuan Madrasah Aliyah se-Kabupaten Surakarta, dan (3) mengetahui hubungan signifikan antara kepemimpinan kepala madrasah dan prestasi kerja guru secara bersama dengan kemajuan Madrasah Aliyah se-Kabupaten Surakarta.

\section{Landasan Teoritis}

\section{Kepemimpinan Kepala Madrasah}

Kepemimpinan adalah proses untuk mempengaruhi orang lain untuk memahami dan setuju dengan apa yang perlu dilakukan dan bagaimana tugas itu dilakukan secara efektif, serta proses untuk memfasilitasi upaya individu dan kolektif untuk mencapai tujuan bersama (Gary Yukl, 2010: 8). Kepemimpinan sebagai sekumpulan serangkaian aktivitas, kemampuan atau kekuatan dan sifat-sifat kepribadian kepala madrasah dalam rangka mempengaruhi dan meyakinkan guru dan siswa agar mereka mau dan melaksanakan tugas-tugas yang dibebankan kepadanya dengan rasa rela, penuh semangat, ada kegembiraan batin serta tidak merasa terpaksa sehingga tercapai suatu tujuan.

Peran kepala madrasah ini, diaplikasikan dalam perilaku kepemimpinan kepala madrasah (Wahjosumidjo, 2008: 119) yang dapat dilihat melalui: Keterbukaan, yang berkaitan dengan merumuskan kebijakan secara demokrasi, musyawarah dengan bawahan, mendelegasikan tugas dengan jelas terhadap guru sehingga guru dapat melaksanakan tugas dengan baik, menetapkan/menentukan tata tertib organisasi dan disepakati oleh guru atau sekolah.

Perhatian terhadap bawahan yang berkaitan dengan membantu pekerjaan guru, meningkatkan etika sosial dan semangat terhadap staf, memberikan gambaran atas usaha perorangan, memberikan motivasi/dorongan semangat dan penghargaan terhadap guru atas keberhasilan guru dalam tugasnya membimbing, 


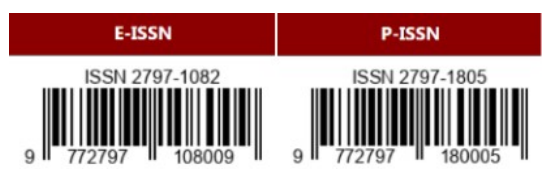

membantu guru yang mengalami kesulitan mengajar maupun masalah pribadi lainya, penuh keramahan dalam menyelesaikan masalah dan bersikap pengasih terhadap bawahan.

Interaksi, yang berkaitan dengan membina hubungan yang harmonis sesama warga sekolah, dapat menyesuaikan diri dengan situasi organisasi yang telah di bentuk sekolah.

Pengambilan keputusan, yang berkaitan dengan (mengembangkan nilai-nilai kehidupan sekolah yang demokratis terhadap warga sekolah, peduli terhadap kekurangan sekolah dan berusaha menyediakan, melengkapinya.

Berdasarkan pengertian di atas, maka kepemimpinan merupakan sifat-sifat, perilaku pribadi, pengaruh terhadap orang lain, pola-pola interaksi, hubungan kerjasama antar peran, kedudukan dari satu jabatan administratif, dan persepsi dari lain-lain tentang legitimasi pengaruh menentukan arah dan tujuan, memberikan bimbingan dan menciptakan iklim kerja yang mendukung pelaksanaan proses administrasi dan proses belajar mengajar. Kepala madrasah dikatakan sebagai pemimpin yang efektif bilamana kepala madrasah mampu menjalankan proses kepemimpinannya untuk mendorong, mempengaruhi dan mengarahkan kegiatan dan tingkah laku kelompoknya.

\section{Prestasi Kerja Guru}

Prestasi kerja merupakan pencapaian hasil yang dapat dinilai menurut prilaku yaitu hasil yang diperoleh oleh individu (kinerja individu), atau kelompok (kinerja kelompok) dan oleh suatu program atau kebijakan (Keban, 2004: 194). Prestasi kerja guru yang dimaksud dalam penelitian ini adalah prestasi kerja yang terdiri dari beberapa subvariabel (Mohamad As'ad, 2005:36), yaitu:

a. Kualitas kerja yang berkaitan dengan guru mampu membuat perencanaan pembelajaran yang meliputi membuat RPP, Silabus, Perencanaan dan Penilaian. Guru melaksanakan pembelajaran dengan urutan yang telah ditulis dalam perencanaan pelaksanaan pembelajaran. Guru melaksanakan penilaian setiap selesai PBM.

b. Kreativitas yang berkaitan dengan guru mampu melakukan inovasi dalam pembelajaran atau melakukan tugas lain misalnya: membuat alat peraga, melakukan pembelajaran dengan berbagai metode, sehingga menjadikan pembelajaran yang menyenangkan. c. Tanggung jawab yang berkaitan dengan sikap guru terhadap pekerjaan, keuletan dengan tugas yang diberikan dan mendahulukan kewajiban daripada hak.

d. Kerjasama yang berkaitan dengan cara guru membangun hubungan dengan siswa teman sejawat dan kepala madrasah.

e. Disiplin kerja yang berkaitan dengan Sikap guru yang dapat dilihat dari ketaatan,

kesungguhan, ketepatan waktu dan

kehadiran/frekuensi absensi dalam pekerjaan.

Berdasarkan pengertian prestasi kerja guru

di atas, maka prestasi kerja guru merupakan gambaran hasil kerja di madrasah. Prestasi kerja diartikan sebagai kemampuan kerja guru dalam melaksanakan tugas yang menjadi tanggung jawabnya guna mencapai hasil yang terbaik, bekerja sama dengan teman sejawat dalam menyelesaikan berbagai masalah pekerjaan.

\section{Kemajuan Madrasah Aliyah}

Keberhasilan madrasah diukur dari keberhasilan pengimplentasian Manajemen Berbasis Sekolah. Kemajuan madrasah adalah adanya perubahan baik secara kualitas maupun kuantitas (Mulyasa, 2009: 49) dalam hal:

a. Penambahan jumlah siswa per tahun. Jumlah siswa yang mendapat layanan pendidikan semakin meningkat.

b. Prestasi siswa dalam standar kelulusan dan non akademik dengan Kualitas layanan pendidikan menjadi lebih baik, yang berdampak pada peningkatan prestasi akademik dan nonakademik siswa.

c. Penambahan sarana prasarana madrasah.

d. Kelancaran hubungan madrasah dengan masyarakat

e. Administrasi sekolah yang semakin sistematis. Dengan demikian, kemajuan madrasah merupakan suatu kondisi dari sebuah madrasah yang telah mencapai mutu dan relevansinya, menjamin keadilan layanan pendidikan yang bermutu bagi setiap anak, meningkatnya efektivitas dan efisiensi madrasah sehingga mencapai kategori sekolah maju dalam berbagai segi standar minimal yang telah ditetapkan pemerintah.

\section{Metode Penelitian}

Penelitian ini bermaksud untuk menguji hubungan kepemimpinan kepala madrasah (X1) dan prestasi kerja guru (X2) sebagai variabel independent dengan kemajuan madrasah sebagai variabel dependen $(\mathrm{Y})$ menggunakan rancangan 
penelitian korelasional. Penelitian korelasi bertujuan untuk mengetahui ada tidaknya hubungan antara dua atau beberapa variable. (Arikunto, 2006: 270)

Populasi pada penelitian ini adalah kepala madrasah dan guru-guru Madrasah Aliyah seKabupaten Surakarta, yaitu MAN 1 Surakarta, MAS Al Kahfi, MAS Al Muayyad, MAN 2 Surakarta, MAS Muallimin Muhammadiyah.

Menurut Suharsimi Arikunto, apabila subjeknya kurang dari 100, lebih baik diambil semua sehingga penelitiannya merupakan penelitian populasi. Tetapi jika jumlah subjeknya lebih dari 100 maka dapat diambil antara 10-15\% atau 20-25\% atau lebih. Penelitian ini menggunakan keseluruhan populasi kepala madrasah yaitu sebanyak 5 orang kepala madrasah dan menggunakan sampel guru sebesar $25 \%$ dari populasi guru, yaitu sebesar $25 \% \mathrm{x}$ 159 orang $=40$ orang, sehingga jumlah sampel keseluruhan sebanyak 45 orang. Teknik pengumpulan data melalui observasi, dokumentasi, dan kuesioner menggunakan skala Likert. Untuk keperluan analisis kuantitatif maka jawaban setiap item instrumen kuesioner diberi skor penilaian. Pilihan item Sangat Baik $=5$, pilihan item Baik $=4$, pilihan item Cukup Baik = 3 , pilihan item Kurang Baik $=2$ dan pilihan item Tidak Baik $=1$

Uji validitas instrumen dimaksudkan agar instrumen kuesioner yang dipakai untuk mendapat data benar-benar tepat mengukur apa yang hendak diukur. Uji reliabilitas instrumen digunakan untuk mengetahui sejauh mana hasil suatu pengukuran dapat dipercaya atau dapat diandalkan. Kedua uji ini merupakan syarat sebelum instrumen ini digunakan dalam proses pengumpulan data. Proses ini dilakukan agar data yang dihasilkan oleh produk ini secara konsisten memberikan hasil yang tetap/sama meskipun digunakan berulang kali dan dalam kurun waktu yang berbeda. Hasil perhitungan statistik dari jawaban responden uji coba terhadap masingmasing instrumen yang dikembangkan menjadi 25 butir pertanyaan tentang kepemimpinan kepala madrasah, prestasi kerja guru, dan kemajuan madrasah.

Teknik analisis data yang digunakan menggunakan analisis statistik deskriptif, pengujian persyaratan analisis (uji normalitas, heteroskedastisitas, multikolinieritas), serta analisis regresi linier dan berganda. Data yang diperoleh kemudian ditabulasikan dan dianalisis dengan menggunakan bantuan software IBM SPSS Statistics 21.

\section{Hasil dan Pembahasan}

Hasil analisis statistik deskriptif variabel kemajuan madrasah $(\mathrm{Y})$ diperoleh mean sebesar 105,4 dengan standar deviasi sebesar 4,137. Variabel kepemimpinan kepala madrasah (X1) diperoleh mean sebesar 88,1 dengan standar deviasi sebesar 7,363. Variabel prestasi kerja guru (X2) diperoleh mean sebesar 89,2 dengan standar deviasi sebesar 7,836. Secara rinci dengan distribusi frekuensi deskripsi masing-masing variabel digambarkan pada diagram berikut.

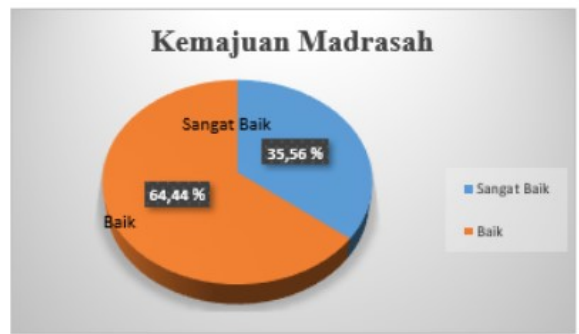

Gambar 1. Deskripsi Persentase Kemajuan Madrasah Aliyah se-Kabupaten Surakarta

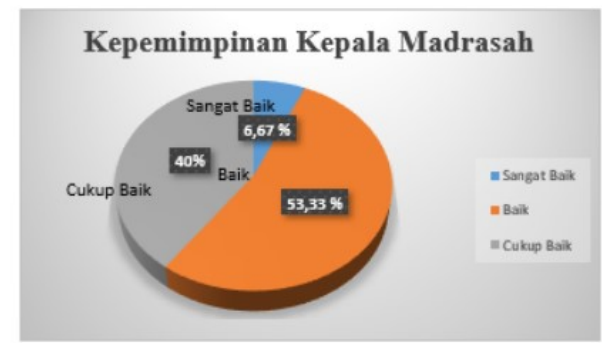

Gambar 2. Deskripsi Persentase Kepemimpinan Kepala Madrasah Alivah se-Kabupaten Surakarta

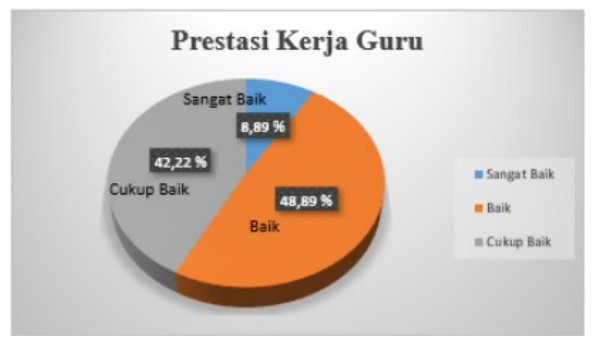

Gambar 3. Deskripsi Persentase Prestasi Kerja Guru Madrasah Alivah se-Kabupaten Surakarta

\section{Uji Hipotesis}

Hubungan Kepemimpinan Kepala Madrasah dengan Kemajuan Madrasah Aliyah se-Kabupaten Surakarta

Hasil perhitungan korelasi pearson dalam tabel korelasi diperoleh hubungan antara variabel kepemimpinan kepala sekolah (X1) dengan kemajuan madrasah (Y) sebesar 0,993, karena nilai tersebut lebih besar dari 0,5 maka hubungan kedua variabel tersebut dikatakan cukup kuat. 


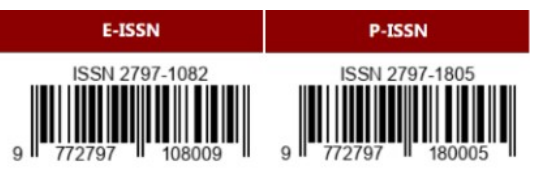

Berarti semakin baik kepemimpinan kepala madrasah, semakin baik pula kemajuan madrasah, atau sebaliknya semakin buruk kepemimpinan kepala madrasah, semakin buruk pula kemajuan madrasah. Ini menjadi petunjuk bahwa untuk memajukan madrasah, para kepala madrasah harus mampu mengaplikasikan perilaku kepemimpinan yang ditunjukkan melalui indikator: (1) keterbukaan, (2) perhatian terhadap bawahan, (3) interaksi, dan (4) pengambilan keputusan.

Berdasarkan hasil analisis korelasi parsial dapat dijelaskan bahwa setelah variabel prestasi kerja guru (X2) dikontrol (dikendalikan) untuk seluruh sampel, maka korelasi antara variabel kepemimpinan kepala madrasah (X1) dengan kemajuan madrasah (Y) menjadi 0,680. Jadi apabila prestasi kerja guru (X2) yang dirasakan/dialami setiap subyek sampel dibuat sama (terkendali), maka hubungan $\mathrm{X} 1$ dengan $\mathrm{Y}$ mengalami penurunan sebesar $0,993-0,680=$ 0,313 .

Hal tersebut menunjukkan adanya pengaruh dari variabel prestasi kerja guru (X2) terhadap hubungan variabel kepemimpinan kepala madrasah (X1) dengan variabel kemajuan madrasah (Y) sebesar $31,3 \%$ dan keeratan/pengaruh X1-Y sebesar $68 \%$.

Berdasarkan hasil uji regresi linear didapatkan pada tabel model summary diperoleh skor R square sebesar 0,917, yang berarti bahwa $91,7 \%$ kemajuan madrasah dipengaruhi oleh kepemimpinan kepala madrasah sedangkan sisanya $8,3 \%$, kemajuan madrasah dipengaruhi oleh variabel lain.

Uraian di atas menunjukkan jika kemajuan madrasah tidak baik/rendah, disebabkan rendahnya kepemimpinan kepala madrasah, dan jika prestasi kerja guru yang ada di lembaga itu lemah, akan dapat mempengaruhi tingkat kemajuan madrasah (menjadi lemah), demikian juga sebaliknya. Dengan demikian dapat dinyatakan bahwa kepemimpinan kepala madrasah mempunyai hubungan yang signifikan dan nyata dengan kemajuan madrasah.

$$
\text { Hasil penelitian ini menunjukan }
$$

bahwa kepemimpinan kepala madrasah mempunyai hubungan dengan kemajuan madrasah, yang berarti semakin bagus kepemimpinan kepala madrasah maka akan semakin meningkatkan kemajuan madrasah. Berdasarkan uraian di atas, hipotesis yang menyatakan ada hubungan yang signifikan antara kepemimpinan kepala madrasah dengan kemajuan Madrasah Aliyah se-Kabupaten Surakarta dapat diterima.

\section{Hubungan Prestasi Kerja Guru dengan Kemajuan Madrasah Aliyah se-Kabupaten Surakarta}

Hasil perhitungan korelasi pearson dalam tabel korelasi diperoleh hubungan antara variabel prestasi kerja guru (X2) dengan kemajuan madrasah $(\mathrm{Y})$ sebesar 0,988 , karena skor tersebut lebih besar dari 0,5 maka dapat dinyatakan bahwa hubungan kedua variabel tersebut cukup kuat. Berarti semakin baik prestasi kerja guru maka semakin baik pula kemajuan madrasah, atau sebaliknya semakin buruk prestasi kerja guru maka semakin buruk pula kemajuan madrasah. Ini menjadi petunjuk bahwa untuk memajukan madrasah maka harus ada upaya peningkatan prestasi kerja guru yang dapat ditunjukkan melalui: (1) kualitas kerja, (2) kreativitas kerja, (3) tanggung jawab, (4) kerjasama, dan (5) disiplin kerja.

Berdasarkan hasil analisis korelasi parsial dapat dijelaskan bahwa setelah variabel kepemimpinan kepala madrasah (X1) dikontrol (dikendalikan), besaran korelasi antara prestasi kerja guru (X2) dengan kemajuan madrasah (Y) berubah (menurun) menjadi 0,851 . Jadi apabila kepemimpinan kepala madrasah (X1) yang dirasakan/ dialami setiap subyek sampel dibuat sama (terkendali), maka hubungan $\mathrm{X} 2$ dengan $\mathrm{Y}$ mengalami penurunan sebesar 0,988-0,851= 0,137 .

Dengan demikian dapat dinyatakan bahwa variabel kepemimpinan kepala madrasah (X1) memiliki pengaruh terhadap hubungan prestasi kerja guru (X2) dengan kemajuan madrasah (Y) sebesar $13,7 \%$ dan keeratan/pengaruh X2-Y sebesar $85,1 \%$.

Berdasarkan hasil uji regresi linear didapatkan pada tabel model summary diperoleh skor R square sebesar 0,977 (lihat lampiran 11), yang berarti bahwa 97,7\% kemajuan madrasah dipengaruhi oleh prestasi kerja guru sedangkan sisanya $2,3 \%$, kemajuan madrasah dipengaruhi oleh variabel lain.

Uraian di atas menunjukan bahwa jika kemajuan madrasah tidak baik/rendah diakibatkan dari rendahnya prestasi kerja guru, dan jika kepemimpinan kepala madrasah yang ada di lembaga itu lemah, akan dapat mempengaruhi kemajuan madrasah (menjadi lemah), demikian juga sebaliknya. Dengan demikian dapat dinyatakan bahwa prestasi kerja guru mempunyai hubungan yang signifikan dan 


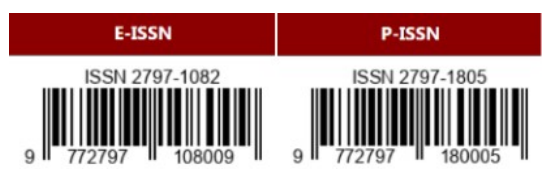

nyata dengan kemajuan madrasah.

Berdasarkan uraian di atas, hipotesis yang menyatakan ada hubungan yang signifikan antara prestasi kerja guru dengan kemajuan Madrasah Aliyah se-Kabupaten Surakarta dapat diterima.

Hubungan Kepemimpinan Kepala Madrasah dan Prestasi Kerja Guru dengan Kemajuan Madrasah Aliyah se-Kabupaten Surakarta

Berdasarkan tabel model summary diperoleh skor $\mathrm{R}$ sebesar 0,988 yang berarti hubungan antara variabel kepemimpinan kepala madrasah (X1) dan prestasi kerja guru (X2) dengan kemajuan madrasah (Y) dinyatakan cukup kuat karena diatas 0,5. Berarti semakin baiknya kepemimpinan kepala madrasah dan prestasi kerja guru, maka semakin meningkatkan kemajuan madrasah, atau sebaliknya. Jika kepemimpinan kepala madrasah dan prestasi kerja guru tidak baik, akan berdampak pada buruknya kemajuan madrasah.

Hasil uji koefisien determinasi diperoleh skor R Square sebasar 0,977 yang berarti bahwa $97,7 \%$ kemajuan madrasah dipengaruhi oleh kepemimpinan kepala madrasah dan prestasi kerja guru, sedangkan sisanya 2,3\% dipengaruhi oleh variabel lain.

Hasil penghitungan analisis regresi berganda pada tabel koefisien diperoleh skor konstanta sebesar 59,301. Skor arah regresi kepemimpinan kepala maadrasah (X1) sebesar 0,154 dan skor arah regresi prestasi kerja guru (X2) sebesar 0,571. Berdasarkan konstanta dan arah regresi tersebut maka persamaan garis regresinya adalah: $\mathrm{Y}=59,301+0,154 \mathrm{X} 1+$ $0,571 \mathrm{X} 2$, yang berarti setiap ada kenaikan satu poin pada variabel $\mathrm{X} 1$ berakibat naiknya skor variabel Y sebesar 0,154, dan setiap ada kenaikan variabel X2 berakibat naiknya skor variabel $\mathrm{Y}$ sebesar 0,571 .

Berdasarkan hasil output regresi ganda juga dapat dilihat besarnya pengaruh masingmasing variabel bebas terhadap kemajuan Madrasah Aliyah se-Kabupaten Surakarta. Tampak bahwa variabel bebas prestasi kerja guru menunjukan keeratan hubungan dengan memberikan kontribusi sebesar 0,881 atau $88,1 \%$. Hal ini lebih besar dibanding variable kepemimpinan kepala madrasah yang memberikan kontribusi sebesar sebesar 0,167 atau $16,7 \%$ (lihat lampiran 12 ).

Berdasaarkan uraian di atas dapat dinyatakan bahwa kepemimpinan kepala madrasah dan prestasi kerja guru memiliki hubungan yang signifikan dan nyata dengan kemajuan madrasah.

\section{Simpulan dan Saran}

\section{Simpulan}

Berdasarkan hasil penelitian dan pembahasan pada bab sebelumnya dapat dirumuskan beberapa simpulan sebagai berikut:

Hasil analisis statistik deskriptif menunjukkan bahwa variabel kepemimpinan kepala madrasah, prestasi kerja guru, dan kemajuan Madrasah Aliyah se-Kabupaten Surakarta memperoleh mean masing-masing sebesar 88,1; 89,2; dan 105,4 berada dalam kategori baik.

Ada hubungan yang signifikan antara kepemimpinan kepala madrasah dengan kemajuan Madrasah Aliyah se-Kabupaten Surakarta sebesar 99,3\%, sedangkan korelasi partial antara kepemimpinan kepala madrasah dengan kemajuan madrasah sebesar $68 \%$, yang berarti prestasi kerja guru (sebagai variabel kontrol) memiliki pengaruh terhadap hubungan kepemimpinan kepala madrasah dengan kemajuan madrasah sebesar 31,3\%, dan kepemimpinan kepala madrasah akan memberikan kontribusi terhadap kemajuan Madrasah Aliyah se-Kabupaten Surakarta sebesar 91,7\%.

Ada hubungan yang signifikan antara prestasi kerja guru dengan kemajuan Madrasah Aliyah se-Kabupaten Surakarta sebesar 98,8\%, sedangkan korelasi partial antara prestasi kerja guru dengan kemajuan madrasah sebesar $85,1 \%$, yang berarti kepemimpinan kepala madrasah (sebagai variabel kontrol) memiliki pengaruh terhadap hubungan prestasi kerja guru dengan kemajuan madrasah sebesar $13,7 \%$, dan prestasi kerja guru akan memberikan kontribusi terhadap kemajuan Madrasah Aliyah se-Kabupaten Surakarta sebesar 97,7\%.

Ada hubungan yang signifikan secara bersama antara kepemimpinan kepala madrasah dan prestasi kerja guru dengan kemajuan Madrasah Aliyah se-Kabupaten Surakarta sebesar $98,8 \%$, Kepemimpinan kepala madrasah dan prestasi kerja guru akan memberikan kontribusi secara bersama terhadap kemajuan Madrasah Aliyah se-Kabupaten Surakarta sebesar 97,7 \%. 
Berdasarkan konstanta dan arah regresi hasil penghitungan analisis regresi berganda diperoleh persamaan garis regresinya adalah: $\mathrm{Y}=59,301+$ $0,154 \mathrm{X} 1+0,571 \mathrm{X} 2$.

\section{Saran}

Berdasarkan hasil penelitian dan pembahasan di atas, maka dapat diajukan saransaran sebagai berikut:

\section{Saran Teoritis}

Berdasarkan penelitian yang telah dilakukan pada Madrasah Aliyah se-Kabupaten Surakarta, maka dapat disarankan pada peneliti berikutnya supaya pada penelitian selanjutnya dapat menambah subjek pada penelitian, hal ini dilakukan agar penelitian benar-benar dapat mewakili keadaan populasi penelitian. Kemudian dapat disarankan agar mencoba faktor lain yang dapat mempengaruhi kemajuan madrasah seperti prestasi siswa, pengelolaan pembiayaan madrasah, serta lain sebagainya dalam penelitian berikutnya.

\section{Saran Praktis}

\section{Bagi Kepala Madrasah}

Ada hubungan yang signifikan antara kepemimpinan kepala madrasah dengan kemajuan madrasah, maka dapat disarankan agar kepala madrasah berusaha untuk lebih dapat meningkatkan kemajuan madrasah dengan memberikan pengaruh yang positif melalui kepemimpinannya untuk dapat meningkatkan prestasi kerja guru dan kemajuan madrasah.

Kepemimpinan kepala madrasah di Madrasah Aliyah se-Kabupaten Surakarta berada pada kategori baik. Agar lebih baik lagi perlu mengoptimalkan manajemen dan supervisi terhadap prestasi kerja guru dalam pelaksanaan proses pembelajaran di kelas. Hal ini dapat meningkatkan prestasi kerja guru dan kemajan madrasah.

\section{Bagi Guru}

Ada hubungan yang signifikan antara prestasi kerja guru dengan kemajuan madrasah, maka dapat disarankan agar para guru terus senantiasa meningkatkan kinerjanya karena dengan adanya peningkatan prestasi kerja yang baik, pendidikan akan dapat tercapai sesuai dengan tujuan yang telah ditetapkan bersama, yang juga turut serta mendorong kemajuan madrasah. Peningkatan kinerja tersebut harus didukung oleh koordinasi yang baik serta kepatuhan guru sebagai bawahan terhadap kepala madrasah sebagai atasannya. Hal itu dapat dilakukan dengan mematuhi segala kebijakan yang diberikan oleh kepemimpinan kepala madrasah, guna untuk mencapai tujuan dalam pendidikan.

Berdasarkan pengolahan data, prestasi kerja guru Madrasah Aliyah se-Kabupaten Surakarta termasuk pada kategori baik. Sejalan dengan tuntutan masyarakat terhadap peningkatan kualitas dan kemajuan madrasah, perlu ditingkatkan kedisiplinan kerja guru dengan pembinaan dan pengawasan yang lebih intensif. Perlu diperhatikan hal-hal yang memberikan kontribusi terhadap peningkatan kinerja guru.

\section{Daftar Pustaka}

Abu Dawud Sulaiman Ibnu al-Asy'ats alSajistami al-Azdiy. Sunan Abu Dawud. Indonesia: Maktabah Dahlan, tt.

Ahmadi dan Syukran Nafis. Pendidikan Madrasah Dimensi Profesional dan Kekinian. Yogyakarta: LaksBang Pressindo, 2010.

Arikunto, Suharsimi. Prosedur Penelitian: Suatu Pendekatan Praktik. Jakarta: Rineka Cipta, 2006.

As'ad, Mohammad. Psikologi Kerja. Jakarta : Rineka Cipta, 2005.

Asrori, Mohib. "Kepemimpinan Kepala Sekolah dalam Meningkatkan Kinerja Guru", www.gurutrenggalek.co.cc. Diakses 23 Agustus 2015.

Damayanti, Sri. Profesionalisme Kepemimpinan Kepala Sekolah", http://akhmadsudrajat.wordpress.com/2008/07/18 /profesionalisme-kepemimpinan-kepala sekolah. Diakses 23 Agustus 2015.

Depag RI. Al-Qur'an dan Terjemah. Semarang. Semarang: Toha Putra.

Departemen Agama RI. Manajemen Madrasah Aliyah. Jakarta: Direktorat Jenderal Pembinaan Kelembagaan Agama Islam, 1999.

Departemen Agama RI. Standar Penilaian Di Kelas, (Jakarta: Direktorat Jenderal Kelembagaan Agama Islam Direktorat Madrasah dan Pendidikan Agama Islam Pada Sekolah Umum, 2003. 
Depdiknas. Standar Kompetensi Guru, Standar Kompetensi Kepala Sekolah, Standar Kompetensi Penngawas (Permendiknas No. 12,13 dan 16 Tahun 2007). Dinas Pendidikan. Jakarta: 2008.

Elcom. Seri Belajar Kilat SPSS 17.Yogyakarta: Andi Offset, 2009.

Gay, L.R., Mills, G.E., dan Airasian, Peter. Educational Research:Competencies for Analysis and Applications. Ohio: Pearson Merrill Prentice Hall, 2006.

Herabudin. Administrasi dan Supervisi Pendidikan. Bandung: CV Pustaka Setia, 2009.

http://www.mtsnbantulkota.sch.id/news37 1_keunggulan_madrasah_dari_sekolah_u mum.ht ml. Diakses 23 April 2015

Institut Agama Islam Negeri (IAIN). Pedoman Penulisan Tesis. Banjarmasin: Institut Agama Islam Negeri (IAIN) Antasari Program Pasca Sarjana, 2015.

Keban. Manajemen Sumber Daya Manusia. Jakarta: Djambatan, 2004.

Lembaga Kajian Pendidikan keIslaman dan Sosial (LekDis). Standar Nasional Pendidikan (PP RI NO. 19 Tahun 2005). Jakarta: Hans Print, 2005.

Mulyasa, Enco. Manajemen Berbasis Sekolah. Konsep, Strategi dan Implementasi. Cet. 12. Bandung: Remaja Rosdakarya, 2009.

Nafis, Ahmadi, Syukran. Pendidikan Madrasah. Dimensi Profesionalisme dan

Kekinian. Cet. II. Yogyakarta: LaksBang Pressindo, 2010.

Nasution, Mulia. Manajemen Personalia.

Jakarta : Djambatan, 2000.

Qomar, Mujamil. Manajemen Pendidikan Islam. Jakarta: Erlangga, 2007.

Saefullah. Manajemen Pendidikan Islam.

Bandung: Pustaka Setia, 2012.

Sahertian, Piet A. Dimensi Administrasi Pendidikan. Surabaya: Usaha Nasional, 1994.

Sugiyono. Metode Penelitian Pendidikan (Pendekatan Kuantitatif, Kualitatif, dan R\&D). Bandung: Alfabeta, 2010.

Suharsaputra, Uhar. Pengembangan Kinerja Guru, http://uharsaputra.wordpress.com. Diakses 23 Agustus 2015.

Tim Dosen Jurusan Administrasi Pendidikan FIP IKIP Malang. Administrasi Pendidikan. Malang: IKIP Malang, 1989. 